\title{
Self-Organized Amphiphiles are Poor Hydroxyl Radical Scavengers in Fast Photochemical Oxidation of Proteins Experiments
}

Zhi Cheng ${ }^{1}$, Charles Mobley ${ }^{1}$, Sandeep K. Misra ${ }^{1}$, Rama S. Gadepalli ${ }^{1}$, Rachel I. Hammond ${ }^{1}$, Leonid S. Brown ${ }^{4}$, John M. Rimoldi ${ }^{1}$ and Joshua S. Sharp ${ }^{1,2,3 *}$

${ }^{1}$ Department of Biomolecular Sciences, University of Mississippi, University, MS 38677

${ }^{2}$ Department of Chemistry and Biochemistry, University of Mississippi, University, MS 38677

${ }^{3}$ GenNext Technologies, Inc. Half Moon Bay, CA 94019

${ }^{4}$ Department of Physics and Biophysics Interdepartmental Group, University of Guelph, Guelph, Ontario N1G 2W1, Canada

*Correspondence to jsharp@olemiss.edu

\section{Supporting Information}




\section{Synthetic methods for TX405A}

\section{General experimental procedures:}

${ }^{1} \mathrm{H}$ NMR spectral data were recorded in deuterated dimethyl sulfoxide (DMSO- $\mathrm{d}_{6}$ ) or deuterated methanol (Methanol- $\mathrm{d}_{4}$ ) on a Bruker $400 \mathrm{MHz}$ spectrometer. Chemical shifts $(\delta)$ were reported relative to tetramethylsilane or solvent as an internal standard. Spin multiplicities were given as s (singlet), bs (broad singlet), d (doublet), t (triplet), q (quartet), dd (double doublet), or m (multiplet). Coupling constants $(J)$ are reported in Hertz $(\mathrm{Hz})$. Experiments requiring anhydrous conditions were performed using glassware that was flame-dried under vacuum and purged with argon. Transfer of reagents was performed by syringes equipped with stainless steel needles that were flushed with argon and kept under positive argon pressure until use.

Preparation of anhydrous Triton X-405 powder (1): An aqueous suspension of Triton X-405 was subjected to freeze-drying for $18 \mathrm{~h}$ to afford Triton X-405 as a white powder. ${ }^{1} \mathrm{H}$ NMR $(400 \mathrm{MHz}$, DMSO- $\left.d_{6}\right) \delta 7.26(\mathrm{~d}, J=8.9 \mathrm{~Hz}, 2 \mathrm{H}), 6.83(\mathrm{~d}, J=8.9 \mathrm{~Hz}, 2 \mathrm{H}), 4.09-3.99(\mathrm{~m}, 2 \mathrm{H}), 3.78-3.64(\mathrm{~m}, 3 \mathrm{H})$, $3.62-3.56(\mathrm{~m}, 2 \mathrm{H}), 3.51(\mathrm{~d}, J=1.8 \mathrm{~Hz}, 121 \mathrm{H}), 3.44-3.38(\mathrm{~m}, 2 \mathrm{H}), 1.68(\mathrm{~s}, 2 \mathrm{H}), 1.29(\mathrm{~s}, 5 \mathrm{H}), 0.67(\mathrm{~s}$, $9 \mathrm{H})$.

Tosylated Triton X-405 (2): Triton X-405 powder (3.0 g; $1.53 \mathrm{mmol}$ ) was dissolved in $5 \mathrm{~mL}$ of anhydrous dichloromethane (DCM) and a solution of 4-toluenesulfonyl chloride (650 mg; $3.4 \mathrm{mmol})$ in anhydrous DCM $(5 \mathrm{~mL})$ was added dropwise with stirring followed by the addition of triethylamine $(0.52$ $\mathrm{mL} ; 3.71 \mathrm{mmol})$. After stirring at room temperature for $16 \mathrm{~h}, 30 \mathrm{~mL}$ of ethyl acetate was added to the thick turbid reaction mixture and the contents were filtered using a sintered glass funnel. The filtrate was collected and rapidly stirred with the addition of three $100 \mathrm{~mL}$ volumes of anhydrous diethyl ether to precipitate the product. After stirring for $18 \mathrm{~h}$, the turbid mixture was centrifuged and the supernatant decanted. The solid material was resuspended with an additional volume of diethyl ether and the process repeated. The viscous sticky solid was collected and dried under high-vacuum yielding $2.8 \mathrm{~g}(88 \%)$ of tosylated Triton X-405 as a white solid. ${ }^{1} \mathrm{H}$ NMR $\left(400 \mathrm{MHz}, \mathrm{DMSO}-d_{6}\right) \delta 9.33(\mathrm{~s}, 1 \mathrm{H}), 7.79(\mathrm{~d}, J=8.3$ $\mathrm{Hz}, 2 \mathrm{H}), 7.56-7.44(\mathrm{~m}, 5 \mathrm{H}), 7.27(\mathrm{~d}, J=8.8 \mathrm{~Hz}, 2 \mathrm{H}), 7.19-7.07(\mathrm{~m}, 3 \mathrm{H}), 6.84(\mathrm{~d}, J=8.8 \mathrm{~Hz}, 2 \mathrm{H}), 4.18$ $-4.00(\mathrm{~m}, 3 \mathrm{H}), 3.73(\mathrm{dd}, J=3.8,2.3 \mathrm{~Hz}, 3 \mathrm{H}), 3.58(\mathrm{dt}, J=4.4,2.9 \mathrm{~Hz}, 4 \mathrm{H}), 3.51(\mathrm{~d}, J=2.2 \mathrm{~Hz}, 120 \mathrm{H})$, 3.45 (s, 4H), 3.08 (q, J = 7.3 Hz, 10H), 2.43 (s, 2H), $2.30(\mathrm{~s}, 4 \mathrm{H}), 1.69$ (s, 1H), $1.30(\mathrm{~s}, 5 \mathrm{H}), 0.68(\mathrm{~s}, 9 \mathrm{H})$.

Amino Triton X-405 (3): $500 \mathrm{mg}$ of 2 was dissolved in $8 \mathrm{~mL}$ of $29 \%$ aqueous ammonia solution and stirred overnight at room temperature. The contents were extracted with chloroform $(15 \mathrm{~mL} \times 3)$, the combined extracts were washed with brine, the organic layer dried with anhydrous sodium sulfate, filtered, and the filtrate was concentrated under rotary evaporation to afford the crude product as a clear colorless sticky residue. This residue was triturated vigorously by dissolving in few drops of ethyl acetate followed by the addition of excess volumes of hexanes $(20 \mathrm{~mL})$ to give a white solid. The solid was washed twice with hexanes and dried under high vacuum resulting in $360 \mathrm{mg}(80 \%)$ of $\mathbf{3}$ as a white solid. ${ }^{1} \mathrm{H}$ NMR (400 MHz, DMSO- $\left.d_{6}\right) \delta 7.27(\mathrm{~d}, J=8.9 \mathrm{~Hz}, 2 \mathrm{H}), 6.84(\mathrm{~d}, J=8.9 \mathrm{~Hz}, 2 \mathrm{H}), 4.09-4.00(\mathrm{~m}, 2 \mathrm{H})$, $3.78-3.66(\mathrm{~m}, 3 \mathrm{H}), 3.61-3.57(\mathrm{~m}, 3 \mathrm{H}), 3.51(\mathrm{~d}, J=2.4 \mathrm{~Hz}, 154 \mathrm{H}), 2.81(\mathrm{~s}, 1 \mathrm{H}), 1.69(\mathrm{~s}, 2 \mathrm{H}), 1.30(\mathrm{~s}$, $6 \mathrm{H}), 0.68(\mathrm{~s}, 9 \mathrm{H})$.

Triton X-405 2',3'-O-Isopropylideneadenosine amide conjugate (4): 2', 3'-Isopropylidene adenosine5'-carboxylic acid (5.0 mg; $0.015 \mathrm{mmol})$ and $\mathrm{N}$-(3-dimethylaminopropyl)-N'-ethylcarbodiimide hydrochloride $(5.0 \mathrm{mg} ; 0.026 \mathrm{mmol}$ ) were dissolved in $1 \mathrm{~mL}$ of dimethyl sulfoxide followed by the addition of $20 \mu \mathrm{L}$ of N,N-diisopropylethylamine. After stirring for 10 minutes at room temperature 3 (19.7 $\mathrm{mg} ; 0.01 \mathrm{mmol}$ ) was added to the solution and the reaction was stirred for 16 hours at room temperature. The reaction was quenched with the addition of $3 \mathrm{~mL}$ of water and the contents were 
transferred into a dialysis bag with $1 \mathrm{kDa}$ molecular weight cutoff and dialyzed overnight with gentle stirring. The chamber included a solvent mixture of $150 \mathrm{~mL}$ water, $30 \mathrm{~mL}$ methanol and $10 \mathrm{~mL}$ dimethyl sulfoxide. The resultant clear aqueous solution was lyophilized to yield $18 \mathrm{mg}(78 \%)$ of 4 as a white crystalline solid. ${ }^{1} \mathrm{H}$ NMR (400 MHz, DMSO- $\left.d_{6}\right) \delta 8.28(\mathrm{~s}, 1 \mathrm{H}), 8.11(\mathrm{~d}, J=1.0 \mathrm{~Hz}, 1 \mathrm{H}), 7.36-7.20(\mathrm{~m}$, $4 \mathrm{H}), 6.84(\mathrm{~d}, J=8.9 \mathrm{~Hz}, 2 \mathrm{H}), 6.34(\mathrm{~d}, J=1.0 \mathrm{~Hz}, 1 \mathrm{H}), 5.38(\mathrm{~d}, J=1.1 \mathrm{~Hz}, 2 \mathrm{H}), 4.58(\mathrm{~d}, J=1.1 \mathrm{~Hz}, 2 \mathrm{H})$, $4.09-4.01(\mathrm{~m}, 3 \mathrm{H}), 3.78-3.66(\mathrm{~m}, 5 \mathrm{H}), 3.51(\mathrm{~s}, 116 \mathrm{H}), 2.55(\mathrm{~s}, 13 \mathrm{H}), 1.69(\mathrm{~s}, 3 \mathrm{H}), 1.54(\mathrm{~d}, J=7.7 \mathrm{~Hz}$, $3 \mathrm{H}), 1.34(\mathrm{~d}, J=8.7 \mathrm{~Hz}, 3 \mathrm{H}), 1.30(\mathrm{~s}, 6 \mathrm{H}), 0.68(\mathrm{~s}, 9 \mathrm{H})$.

Triton X-405 adenosine amide conjugate TX405A (5): $15 \mathrm{mg}$ of 4 was dissolved in $500 \mu \mathrm{L}$ of $80 \%$ aqueous trifluoroacetic acid and stirred for $3 \mathrm{~h}$ at room temperature. The solvents were removed by rotary vacuum evaporation and the residue was reconstituted in $2 \mathrm{~mL}$ of chloroform and further dialyzed overnight with a $1 \mathrm{kD}$ molecular weight cutoff in a chamber comprising $200 \mathrm{~mL}$ of chloroform. The material was dried under high vacuum to obtain $12 \mathrm{mg}$ of $5(86 \%)$ as a clear amorphous solid. ${ }^{1} \mathrm{H}$ NMR $\left(400 \mathrm{MHz}\right.$, methanol- $\left.d_{4}\right) \delta 8.34(\mathrm{~d}, J=9.1 \mathrm{~Hz}, 2 \mathrm{H}), 7.31(\mathrm{~d}, J=8.9 \mathrm{~Hz}, 2 \mathrm{H}), 7.02(\mathrm{~d}, J=8.6 \mathrm{~Hz}, 1 \mathrm{H})$, $6.87(\mathrm{~d}, J=8.8 \mathrm{~Hz}, 1 \mathrm{H}), 6.06(\mathrm{~s}, 2 \mathrm{H}), 4.52(\mathrm{~d}, J=1.5 \mathrm{~Hz}, 1 \mathrm{H}), 4.37(\mathrm{dd}, J=4.9,1.5 \mathrm{~Hz}, 2 \mathrm{H}), 4.23-4.06$ $(\mathrm{m}, 4 \mathrm{H}), 3.96-3.75(\mathrm{~m}, 7 \mathrm{H}), 3.74-3.58(\mathrm{~m}, 148 \mathrm{H}), 1.76(\mathrm{~s}, 3 \mathrm{H}), 1.36(\mathrm{~s}, 7 \mathrm{H}), 0.74(\mathrm{~d}, J=8.0 \mathrm{~Hz}, 9 \mathrm{H})$.

\section{Citations}

1) Hai, T.T.., Markoski, L.J., Pereira, D.E., and Nordhaus, M. US Patent No. 2003/0149307 A1

2. Umino, T., Yoshioka, K., Saitoh, Y., Minakawa, N., Nakata, H. and Matsuda, A. Nucleosides and Nucleotides. 200. Reinvestigation of 5 '-N-Ethylcarboxamidoadenosine Derivatives: Structure- Activity Relationships for P3 Purinoceptor-like Proteins. Journal of Medicinal Chemistry 44, 208-214 (2001) 
Triton X-100

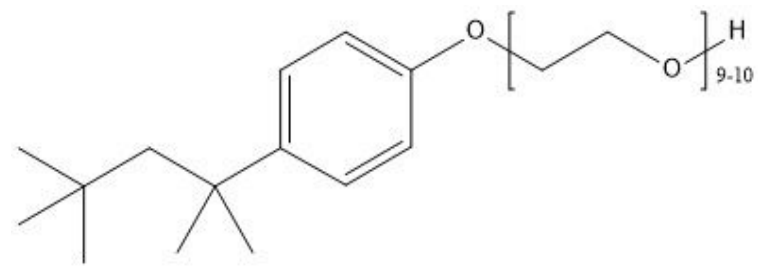

Triton X-405

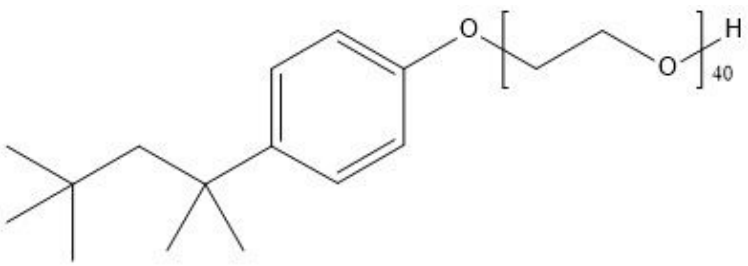

Figure S1. Chemical structures of Triton X-100 and Triton X-405. The detergents differ by the length of the polyethylene glycol hydrophilic chain. 


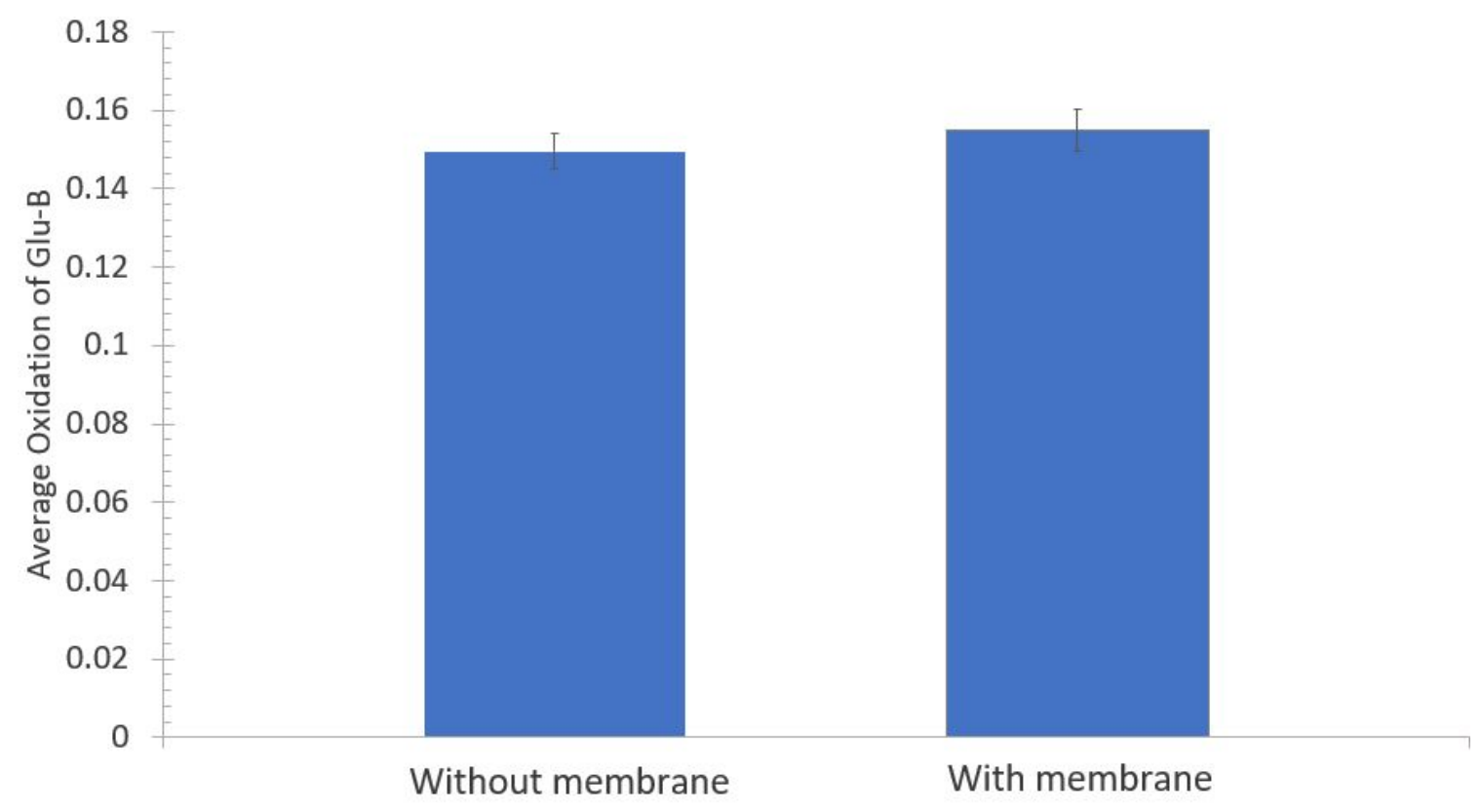

Figure S2. FPOP data for Glu-B peptide with or without extracted membranes. The addition of extracted cellular membranes at a concentration of $6400 \mathrm{cells} / \mu \mathrm{L}$ showed no difference in the peptide oxidation. 


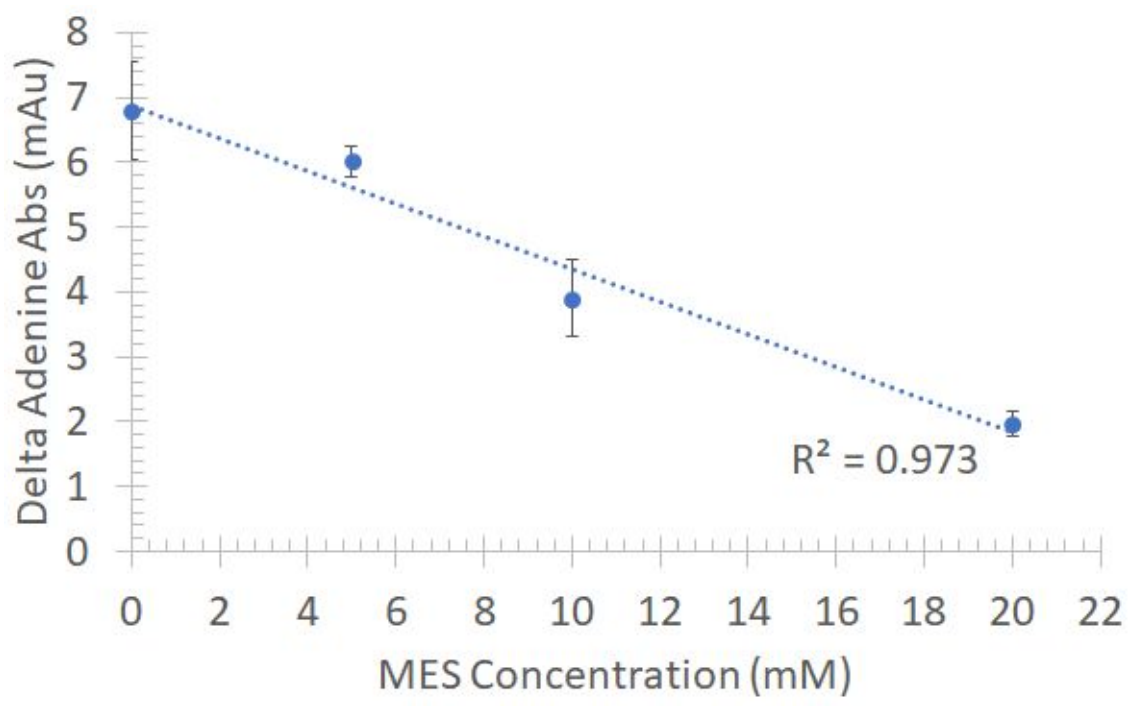

Figure S3. Inline adenine dosimetry confirms radical scavenging of MES. As the concentration of MES buffer increases, the $\triangle \mathrm{Abs}_{265}$ (indicative of effective radical dose) decreases, showing MES buffer acted as a hydroxyl radical scavenger in these conditions. 


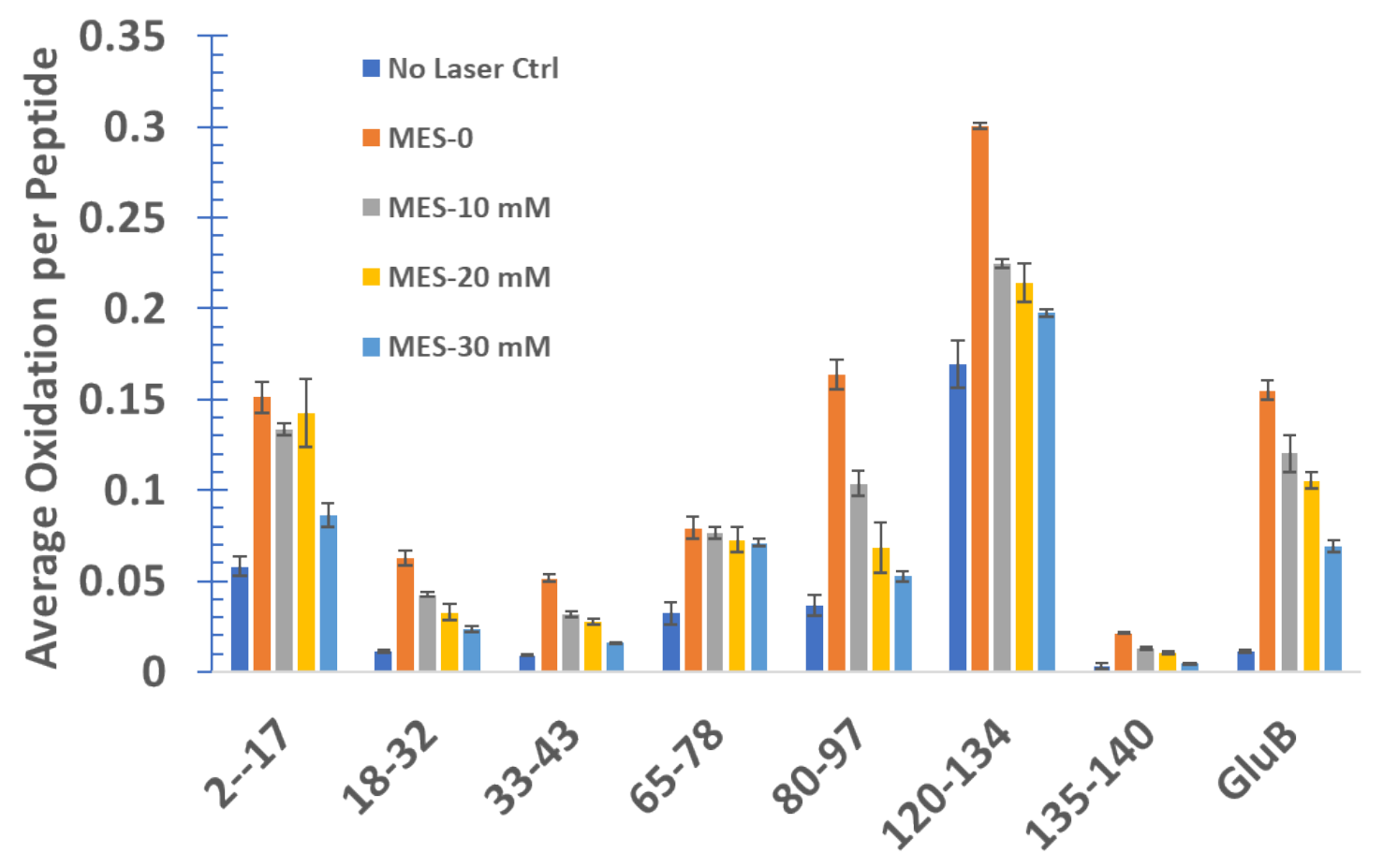

Figure S4. Peptide and protein oxidation confirm radical scavenging of MES. As the concentration of MES buffer increases, the amount of oxidation of all tryptic peptides from myoglobin and Glu-B peptide decreases, showing MES acted as a hydroxyl radical scavenger under these conditions. 


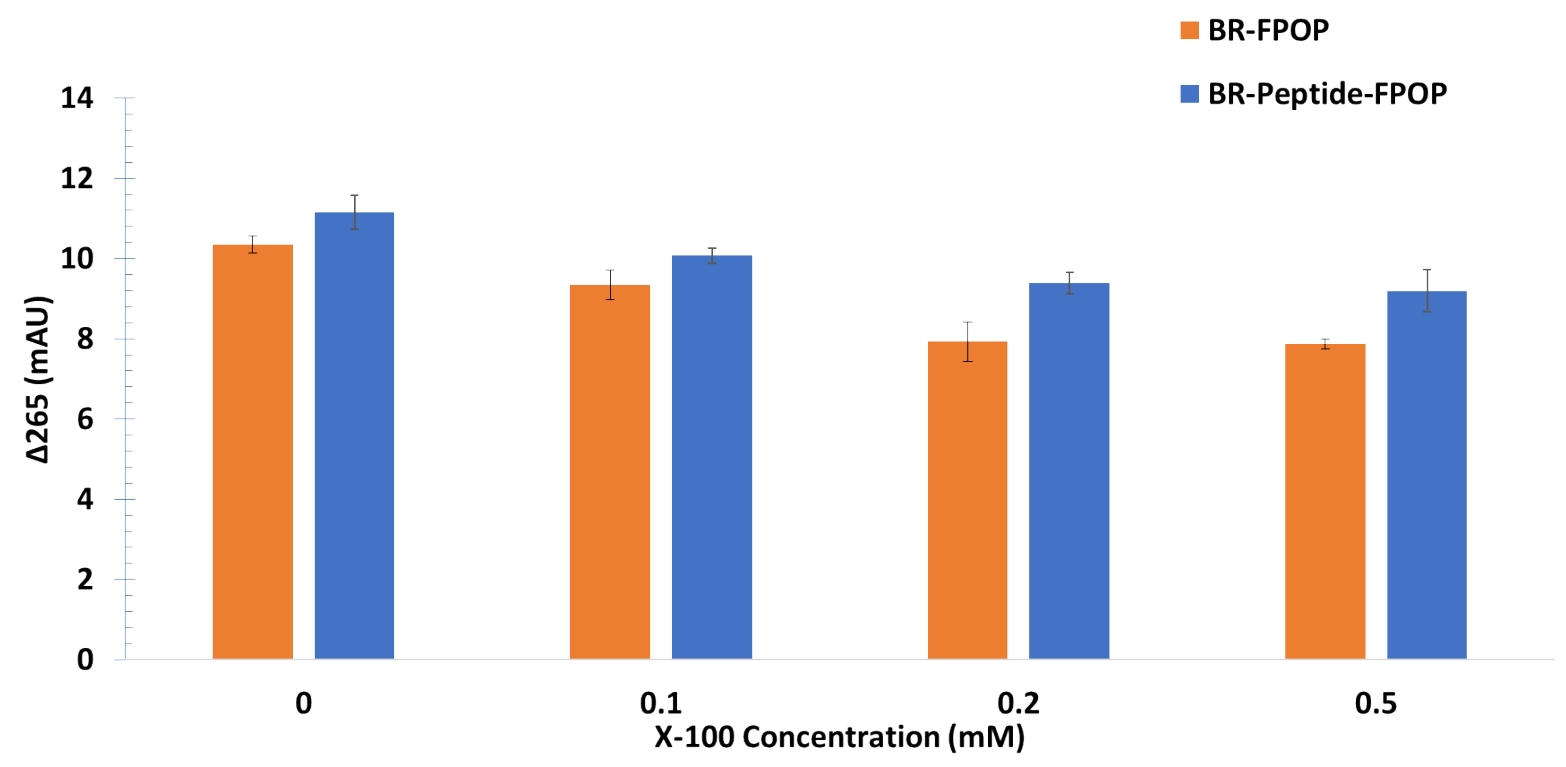

Figure S5. Inline dosimeter result for both integral BR (Orange) and digested BR peptide (Blue) radical activity under different concentration of $\mathrm{X}-100$. For both set of samples, the $\Delta \mathrm{Abs}_{265 \mathrm{~nm}}$ shows a decrease of adenine absorption when detergent is below the $\mathrm{CMC}(0.1 \mathrm{mM})$. Once the detergent reaches its CMC, the adenine absorption remains stable $(0.2$ and $0.5 \mathrm{mM})$. 


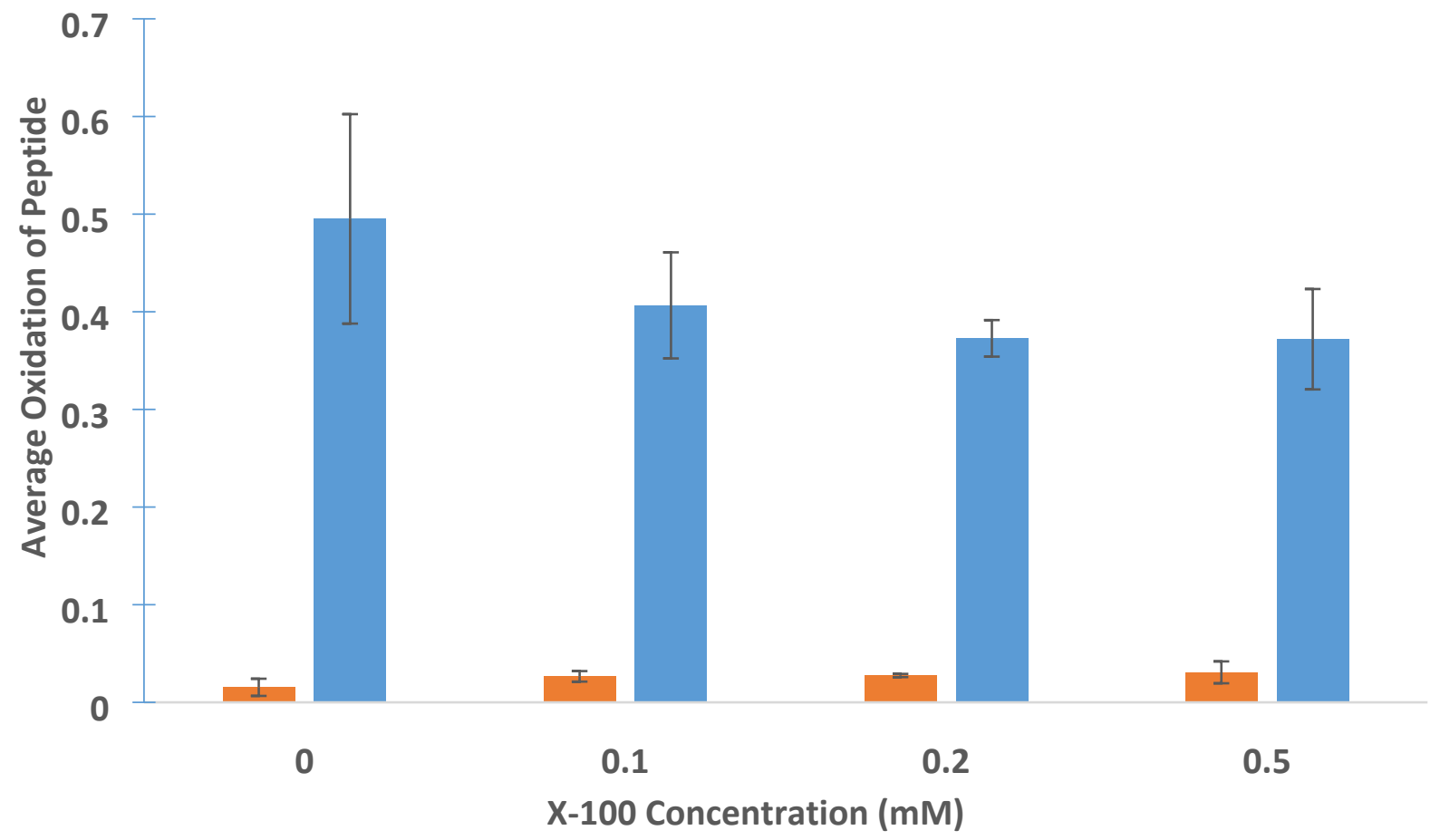

Figure S6. BR extracellular peptide 72-80 oxidation level from (orange) no laser control and (blue) FPOP conditions. 


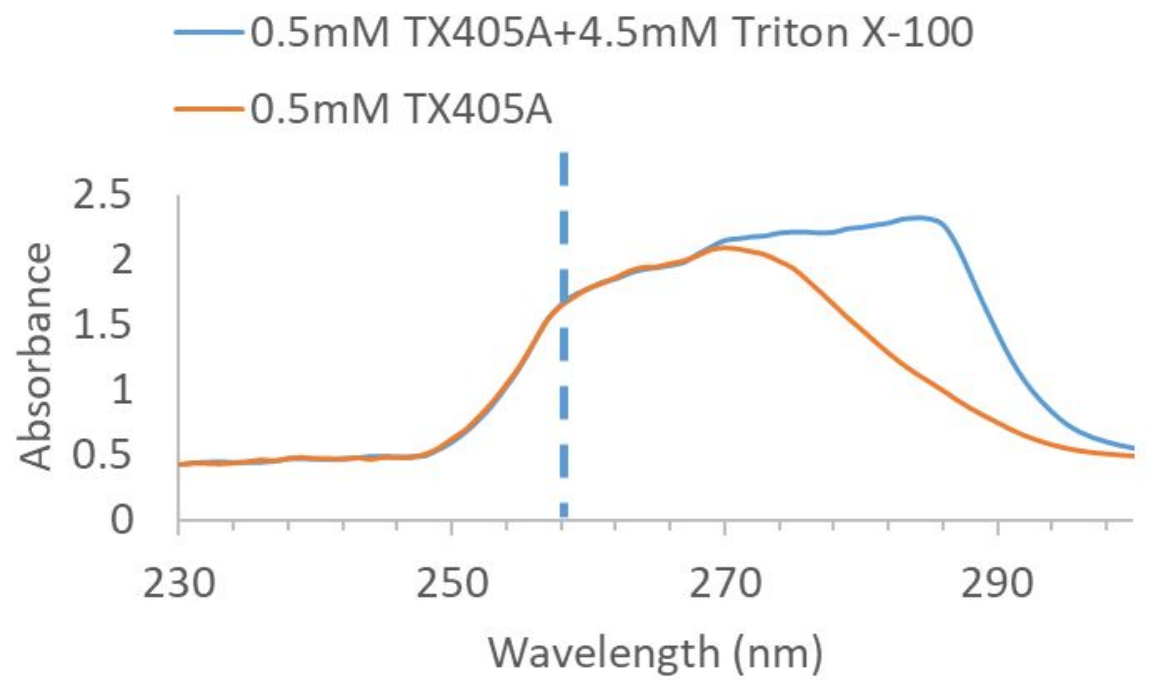

Figure S7. UV absorbance (baseline corrected) of (orange) $0.5 \mathrm{mM}$ TX405A, below the $0.9 \mathrm{mM} \mathrm{CMC}$ of Triton X-405 and (blue) $0.5 \mathrm{mM} \mathrm{TX} 405 \mathrm{~A}$ and $4.5 \mathrm{mM}$ Triton X-100, above the $0.2 \mathrm{mM}$ CMC of the 1:9 mixed micelle. The adenine absorbance band at $260 \mathrm{~nm}$ (blue dashed line) shows no bathochromic shift in the mixed micelle versus the solvated monomer, indicating that the adenine chromophore is fully water solvated in the mixed micelle. The new band at $\sim 285 \mathrm{~nm}$ in the mixed micelle represents the phenyl ring of the Triton $\mathrm{X}-100$. 